ADRIAN MiAnECKI

Uniwersytet Mikołaja Kopernika w Toruniu

\title{
MOTYW KAZIRODZTWA W POLSKIM FOLKLORZE TRADYCYJNYM
}

Według współczesnej definicji słownikowej, kazirodztwo (z łac. incestum, incestus - występny, nieczysty) to „utrzymywanie stosunków płciowych z osobą spokrewnioną w linii prostej lub rodzeństwem bądź z osobą adoptowaną" (Szymczak 1988: 906). Podobnie określa ten czyn art. 201 polskiego Kodeksu karnego, zwalniając z odpowiedzialności sankcjonowanej przez ten artykuł linie boczne rodziny: wujów, stryjów, ich bratanice, siostrzenice itd. ${ }^{1}$ Prawo wyróżnia kazirodztwo typu rodzicielskiego - czyli stosunki między matką lub ojcem a dziećmi - oraz kazirodztwo braterskie - czyli współżycie między rodzeństwem, bez względu na to, czy łączą je więzy krwi (mają wspólnych rodziców), czy też nie (pochodzą z dwóch różnych małżeństw, są adoptowane itp.). Istnieją również pojęcia kazirodztwa bezwolnego (przypadek starotestamentowego Lota, spojonego alkoholem przez córki w celu obcowania, które miało przedłużyć ich ród czy nawet gatunek) oraz kazirodztwa bezwiednego (casus Edypa). Istotne, że art. 201 przez kazirodztwo rozumie stosunki dobrowolne - obcowania wymuszone podpadają pod inne przepisy prawa karnego, stąd też coraz częściej mówi się np. o gwałcie kazirodczym. W latach 2000-2008 liczba stwierdzonych spraw kazirodczych w Polsce wynosiła rocznie średnio ok. 40 wypadków, przy czym nie jest w tych statystykach ujęty ani typ kazirodztwa, ani kwestia dobrowolności (lub nie) opisywanych czynów (Raczek 2012: 58)². Oczywiście, mówimy jedynie o wypadkach ujawnionych. Nieujawnionych - w świetle badań przeprowadzonych np. w Stanach Zjednoczonych - może być nawet 50-krotnie więcej (Gromska, Masłowski, Smoktunowicz 2002: 268).

Przywołanie powyższych statystyk wynika $z$ chęci znalezienia jakiegokolwiek punktu odniesienia dla ewentualnej skali zjawiska w odniesieniu do dawnej kultury wiejskiej. Problem polega bowiem na tym, że podejmując próbę nakreślenia choćby w najogólniejszym stopniu realnego tła społecznego omawianego problemu, zwłaszcza w odniesieniu do odleglejszej przeszłości, napotykamy na niemal całkowitą pustkę informacyjną, powodowaną zarówno brakiem danych, jak i brakiem opracowań. W ujęciu historycznym o zagadnieniu mogłyby traktować przede wszystkim prace poświęcone obyczajowości erotycznej dawnych wieków oraz studia z zakresu historii prawa. Tych pierwszych w Polsce jest jak na lekarstwo - zajmowali się tym zagadnieniem bardzo nieliczni autorzy, jak Bohdan Baranowski (1955), Zbigniew Kuchowicz (1982), Tomasz Wiślicz (2001 - tu podrozdział Etyka seksualna chłopów a wzorzec chrześcijański; 2004) czy Adam Krawiec (2000). Lepiej natomiast prezentuje się pod tym względem stan badań z historii przestępczości i penalizacji, by wymienić monografię Marcina Kamlera (2010 - tam też obszerna bibliografia zagadnienia). Bez wątpienia w znacznym stopniu na tej sytuacji zaważył fakt zniszczeń, jakim uległy w zawieruchach dziejowych archiwa polskie sadowe.

Zagadkowy jest bowiem niemal całkowity brak odniesień w dobie średniowiecza i staropolskiej do kazirodztwa zarówno w sensie istnienia czy stanowienia określonych regulacji prawnych, jak i konkretnych zapisów z rozpraw pomieszczonych w księgach sądowych. W zbiorach praw można spotkać się zatem $\mathrm{z}$ napiętnowanymi rozbojami,

\footnotetext{
${ }^{1}$ Ustawa z dnia 6 czerwca 1997 r. Kodeks karny, art. 201 (Dz.U. z 1997 Nr 88, poz. 553).

2 Por. raport policyjny Przestępstwa przeciwko wolności seksualnej i obyczajowości (197-205). Pozyskano z: http://www.statystyka.policja.pl/portal/st/1108/63502/Kazirodztwo_art_201.html.
} 
kradzieżami, fałszerstwami, morderstwami, dzieciobójstwami, a w sferze obyczajowości seksualnej - cudzołóstwem, prostytucją, stręczycielstwem, pedofilią, gwałtami (przez które, nawiasem mówiąc, rozumiano także współżycie dwojga ludzi bez zgody o p i e k u n ó w jednego $\mathrm{z}$ nich, choć już niekoniecznie ten sprzeciw musiała wyrażać osoba biorąca udział $\mathrm{w}$ samym akcie), zbliżeniami $\mathrm{z}$ istotami demonicznymi (duchami zmarłych, diabłami itd.), jak też - ,grzechami przeciw naturze", do jakich zaliczano współżycie ze zwierzęciem (łac. bestialitas, pol. skucić), stosunki homoseksualne oraz stosunki uniemożliwiające poczęcie. Nie ma jednak osobnych przepisów dotyczących kazirodztwa (przynajmniej w najdawniejszych zbiorach) i w zasadzie nie ma procesów toczących się w tego typu sprawach. Marcin Kamler, przebadawszy 2600 procesów odnotowanych w księgach miejskich sądów kryminalnych (tzw. księgach złoczyńców) w latach 1550-1650, odnalazł jedynie dwie tego typu sprawy, obie z Poznania: w 1556 r., sądzono wtedy niejakiego Błażeja Tomalę za współżycie z żoną swego stryjecznego brata (owdowiałą), i z 1583 r., w którym oskarżony miał utrzymywać wieloletnie stosunki z siostrą żony. Komentarz badacza do tego fragmentu jego pracy mówi wiele: „Nie umiem wytłumaczyć, dlaczego księgi zawierają tak mało oskarżeń o kazirodztwo - można przypuszczać, iż wspólne mieszkanie $\mathrm{z}$ pasierbicami i pasierbami (zwłaszcza sypianie $\mathrm{w}$ jednej izbie) prowokowało do tego rodzaju przestępstwa" (Kamler 2010: 286-287). Zwróćmy na marginesie uwagę, że oba wypadki według współczesnej normy prawnej w ogóle nie spełniałyby warunku kazirodztwa - być może jest to jedno ze świadectw stopniowo malejącej roli związków pokrewieństwa i powinowactwa (czy nawet, szerzej, kolektywizmu archaicznych struktur społecznych - w znaczeniu, jakie nadał temu określeniu Karol Modzelewski (2004)) na rzecz relacji sąsiedzko-towarzyskich i zawodowych, co obserwowano już wcześniej na podstawie ubożejącej wraz z upływem wieków terminologii rodzinnej (Szymczak 1966).

Słowa Kamlera są zrozumiałe tym bardziej, jeśli będziemy mieli na uwadze fakt, iż zachowania erotyczne naszych przodków miały charakter o wiele bardziej swobodny - jak określają badacze tej sfery życia: rubaszny czy wręcz gruby - niż to, co dla nas stanowi względnie do niedawna stanowiło akceptowalną normę. Zebrany przez Tomasza Wiślicza materiał zdaje się wskazywać, że mimo usilnych starań kościoła i dworu, by podstawą moralności seksualnej uczynić instytucję małżeństwa, zarówno przed zawarciem związku, jak i po nim w środowisku chłopskim cieszono się dość znaczną swobodą w korzystaniu z uciech cielesnych, przynajmniej do momentu, kiedy nie pojawił się niechciany owoc tychże, czyli dziecko. Bardzo wymowne jest też tragiczne zdarzenie z 1715 r.: wójt jednej z wsi w Beskidzie Żywieckim został oskarżony i skazany za zabicie brzemiennej służki. Czynu tego dokonał w akcie zemsty, ponieważ dziewczyna zaszła w ciążę z kochankiem, z którym od dłuższego czasu wójt utrzymywał intymne kontakty. Co więcej, powodem takich jego upodobań miał być fakt, iż reprezentant gromady ,to był styran, albo mieszaniec, to jest męskie i białogłowskie przyrodzenie miał mieć w sobie" (Wiślicz 2004: 57). Abstrahując już od hermafrodytyzmu (androgynizmu), zwróćmy uwagę na ważny szczegół: człowiek ten, żyjący w niewielkiej społeczności lokalnej, jak najbardziej tradycyjnej, i pomimo regulacji prawnych jednoznacznie piętnujących homoseksualizm, najwyraźniej nie miał żadnych problemów związanych ze swoim statusem społecznym, skoro pełnił nawet funkcję wójta, a jego kłopoty zaczęły się dopiero po dokonaniu zbrodni morderstwa. Idźmy jednak dalej: wiek XVIII to czas, kiedy wzrosła liczba spraw o inny „grzech przeciw naturze", tzn. zoofilię. W księgach sądowych zaczęły mnożyć się zapisy, w których np. gromada skarży jednego ze swych ziomków „o pewną robotkę smieszną 
a smierdzącą", przy czym nie wiadomo czy z kobyłką, czy z jałówką, albo zeznania, w jakich oskarżony „będąc pytany od mistrza [tj. kata], dlaczegoś to z kobyłą uczynieł, odpowiedział, że miał wolę zgwałcić Stróżową, która mu odpowiedziała: masz żonę, idź do diabła, daj mi pokój, wyszedszy z domu jego Stróżowa, kobyłę w swojej zapalonej lubieżności wprowadziwszy do izby, popełnieł z nią bestialitatem" (Wiślicz 2004: 56). Oczywiście, fakt mnożenia się tego typu opisów w polskich dokumentach sądowych nie jest wynikiem jakiejś radykalnej zmiany upodobań erotycznych naszych przodków. Wiek XVIII, a zwłaszcza jego druga połowa, to swoistego rodzaju cezura. Jest to bowiem epoka, w której intensywna, kontrreformacyjna działalność kościoła zaczęła przynosić owoce $\mathrm{w}$ postaci powszechnego i gruntownego zaszczepienia etyki chrześcijańskiej również w środowisku wiejskim (choć być może w mniejszym stopniu niż w miastach i miasteczkach, por. Hernas 1965: 90-94). Przejawiało się to, z jednej strony, narastaniem coraz bardziej radykalnych postaw wobec dawniejszej swobody seksualnej, objawiającej się większą liczbą rozpraw (np. w wyniku donosów), a z drugiej, w istotny sposób wpłynęło na tradycyjny folklor, który z tego względu zaczęły do głębi przenikać wątki i treści utrzymane w duchu chrześcijańskiej moralności, co tak dobrze widoczne jest w materiałach zapisanych w wieku XIX. Jak się wydaje, jednym $\mathrm{z}$ gatunków w najmniejszym stopniu dotkniętych przez te zmiany jest klasyczna ludowa bajka magiczna.

Próbując odnaleźć wytłumaczenie tej swoistej „niewidzialności” kazirodztwa w konkretnych sytuacjach społecznych, nie sposób nie odwołać się do zaplecza etnologicznego. Jak wiadomo, kazirodztwo należy do nielicznych tabu uniwersalnych (obok kanibalizmu np.), tzn. zakazów, które obowiązywały w każdej kulturze ludzkiej i w każdej epoce historycznej. Bezwzględny zakaz incestu obowiązujący był (i jest) jednak wyłącznie w obrębie rodziny pierwiastkowej (rodzice, dzieci, ewentualnie dziadkowie) - w odniesieniu do dalszych krewnych i powinowatych restrykcja ta w różnych kulturach przybierała różne formy i obostrzenia; jak zresztą już widzieliśmy, przyjmuje ona różny „zasięg” nawet w obrębie tej samej kultury, ale różnych epok. Tabu incestu należy do fundamentalnych kategorii antropologii kulturowej, rozpoznane zostało już na początku istnienia tej dyscypliny, zajmowali się nim właściwie wszyscy czołowi etnologowie, by wspomnieć tylko Bronisława Malinowskiego (1980; 1987) czy Claude'a Lévi-Straussa (2011), w wypadku którego zresztą badanie tego tabu stało się kamieniem węgielnym antropologii strukturalnej. Do dziś cieszy się w refleksji etnologicznej niezmiennie powszechnym i intensywnym zainteresowaniem, czego dowodzą choćby prace Lindy Stone (2012) poświęcone płci kulturowej. Ze względu na oczywiste ograniczenia nie chcę $\mathrm{w}$ tym miejscu przytaczać dziejów rozumienia tego tabu, koncepcji genezy zakazu czy teorii jego wpływu na konkretne zachowani kulturowe wśród społeczności tradycyjnych. Na potrzeby artykułu przyjmuję tylko roboczo, że prawdopodobnie to właśnie obowiązywanie tabu pełniło doniosłą rolę w tak skutecznym ukrywaniu zjawisk kazirodczych, że niemal nie wypływały one „na powierzchnię" życia społecznego - w kontekście tego, co zostało do tej pory powiedziane, po prostu trudno jest przyjąć tezę o nieistnieniu zachowań incestualnych w dawnej kulturze Polski.

Trzeba powiedzieć, że tej społecznej (pozornej) nieobecności czynów kazirodczych, towarzyszy sporadyczność występowania tytułowego motywu w folklorze tradycyjnym. W poezji ludowej kazirodztwo pojawia się w nielicznych realizacjach jednego $\mathrm{z}$ wątków balladowych (w zasadzie jedynego fabularyzowanego gatunku pieśni, jaki dotrwał w Polsce do czasu, kiedy zaczęto spisywać literaturę ludową). Opowiada o tym, jak to do karczmy zawitał młodzieniec wraz drużyną 
towarzyszy. Napotkaną karczmarkę namawia do nastręczenia mu jej służki, Kasieńki, co też starsza kobieta czyni z ochotą przekupiona kilkoma złotymi. Po wspólnie spędzonej nocy (względnie w trakcie ścielenia łóżka) zrozpaczona dziewczyna żali się, że tak nisko upadła, a wszak pochodzi z wójtowskiej rodziny. W wyniku rozmowy okazuje się, że są rodzeństwem, które o sobie nie wiedziało - zdjęty grozą (niedoszłego) czynu bohater obcina sobie głowę (Wężowicz-Ziółkowska 1991: 55). Jakkolwiek incest - jego realizacja lub tylko możliwość - pojawia się tylko w tej grupie ballad, warto odnotować, że sama para protagonistów, brat i siostra, jest motywem niezmiernie częstym w opisywanym gatunku folkloru. Brat jest tym, który zazwyczaj wymierza karę bądź siostrze za utratę dziewictwa, bądź uwodzicielowi, który zbałamucił dziewczynę, czyli wykazuje, nazwijmy to, ,prerogatywy” charakterystyczne dla opiekuna, a zwłaszcza, jak moglibyśmy oczekiwać, ojca. Ta ostatnia postać jednak w balladach niemal w ogóle nie występuje, natomiast inną, równie popularną jak brat i ukazaną w dokładnie tych samych funkcjach, jest mąż. Trudno rozstrzygnąć na tym etapie, czy zastanawiająca tożsamość funkcji brata i męża, i ich pełna wymienność w konkretnych wariantach, jest tylko przypadkiem czy może śladem jakichś dawnych (mitologicznych?) tradycji, zważywszy że w typach fabularnych zbliżonych do omawianego pojawiają się, choć zdecydowanie rzadziej, także król (pan), Bóg i - po prostu - kochanek. Odnotujmy tu jednak tę obserwację, ponieważ za chwilę wróci ona ze zwielokrotnioną siłą.

W odróżnieniu od poezji proza ludowa częściej posługiwała się tytułowym motywem. W opowieściach, które osadzają akcję w epoce tworzenia i urządzania świata, czyli w tzw. bajkach ajtiologicznych, można zetknąć się z niezbyt popularnym wątkiem mówiącym o powstaniu kwiatów o nazwie bratki. Według ludowego gawędziarza: „,...] brat i siostra, nie wiedząc o swojém pokrewieństwie, pobrali się. Dowiedziawszy się potém, w jak blizkim zostawali ze sobą związku krwi, rozpaczali, a Bóg przemienił ich w kwiat dwóbarwny, jeden lilijowy, lub niebieski, drugi żółty" (Gustawicz 1882: 307) ${ }^{3}$. Opowieść ta jest bardzo zajmująca, ponieważ mocno łączy się $\mathrm{z}$ tradycją rosyjską (nie znam analogicznego materiału polskiego), zawierającą przekazy mówiące o rodzeństwie Marii i Iwana, którzy, dopuściwszy się incestu, zostali za karę przemienieni w kwiatek. Co ciekawsze, Maria i Iwan nie są bohaterami wyłącznie folkloru, ale postaciami, których obecność (symboliczna oczywiście) jest konieczna w obrzędzie o szczególnym znaczeniu - obrzędzie stwarzania nowego świata w skali mikro, tzn. budowy domu. Jak zanotował Albert Kaszfułłowicz Bajburin, w trakcie rozpoczynania budowy, kiedy położone zostały dwa pierwsze wieńce, inicjowana była rytualna uczta w miejscu przyszłego świętego kąta, na jaką muszą być zaproszeni ludzie o tych imionach - jeśli nie ma takich wśród domowników lub cieśli, są specjalnie sprowadzani spoza kręgu najbliższych. W opinii uczonego:

Jest to bardzo ciekawy przykład reminiscencji mitologicznej w rytuale, jeśli uwzględnimy motyw kazirodztwa pomiędzy bratem i siostrą, przemienionych za karę w kwiatek Iwan i Maria. Jak dobrze wiadomo, kazirodztwo $w$ wyobrażeniach ludowych wiąże się $\mathrm{z}$ maksymalną urodzajnością. Że nie jest to jednostkowy wtręt do struktury rytuału budowy, mówią o tym dane

\footnotetext{
${ }^{3}$ Opowieść należy do typu T2660 Bratki. Tu i dalej numeracja wątków za: Krzyżanowski (1962-1963). Nadmieńmy, że istnieje też wariant traktujący powstanie bratków jeszcze bardzie dosłownie, jako konsekwencja zakochania w sobie dwóch braci: „A u nas pono w dawnych czasach zdarzyło się, że było dwu braci, co się bardzo kochali, i byli pono najładniejsi na świecie. Tak oni nic nie robili, jino się na siebie patrzyli, i tak se gadali: „Jakiś ty śliczny, aniołowie w niebie nie są ładniejsi od ciebie?” Za to Pan Bóg ich skarał i zamienił w kwiatek, co się nazywa bratek" (Gustawicz 1882: 307-308). Opowieść zaczerpnięta z pracy Szymona Matusiaka 1881: 164.
} 
z obszaru białoruskiego, świadczące że pomiędzy bierwiona kładzie się trawy, zebrane w wigilię nocy świętojańskiej. Iwan i Maria należą właśnie do repertuaru obrzędowości świętojańskiej. W każdym bądź razie istnieją podstawy, aby przypuszczać, że operacja łączenia bierwion w wieniec w świadomości ludu wiązała się z motywem kazirodztwa [Bajburin 1990: 63].

Dwa kolejne typy fabularne zawierają motyw incestu rodzicielskiego, którego sprawcami są matka i syn. Przynależą do gatunku bajek nowelistycznych, czyli bogatego zbioru opowieści ludowych o wysoce zagmatwanej poetyce, co wynika z ich bardzo skomplikowanej proweniencji, w znacznym stopniu zadłużającej się w różnorodnym średniowiecznym i wczesnonowożytnym piśmiennictwie zachodnioeuropejskim (exempla, historie rzymskie, wczesne nowele), a poprzez te tradycję sięgającym też do spuścizny antyku. W opinii Violetty Wróblewskiej (2007: 319-320): „[Stanowią] rodzaj formy synkretycznej, heterogenicznej, czyli typ konwencji sytuującej się na granicy opowieści bajkowych i niebajkowych, fantastycznych i realistycznych, między exemplum, bajką magiczną a facecją, więc jedynie inwencja gawędziarza może zdecydować o ostatecznym kształcie oraz charakterze konkretnej realizacji”.

Takie też są wątki Edyp (T 931) i Grzegorz papież (T 933). Pierwszy, jak nietrudno się domyślić, stanowi ludową wersję starożytnej opowieści, która, dodajmy, nawet $\mathrm{w}$ swym pierwotnym literackim opracowaniu, dokonanym przez Sofoklesa, niekoniecznie wiernie musiała oddawać rzeczywisty kształt tego mitu (Graves 1974: 348-349) ${ }^{4}$. Opowieść ta, wielokrotnie przerabiana jeszcze w antyku i istniejąca w wielu wersjach, wraz ze świtem nowego millenium cieszyła się sporą popularnością (włączona została np. przez Jakuba de Voragine do Złotej legendy), a nabierając przy tym kolorytu epoki, łączyła się $\mathrm{z}$ tradycjami chrześcijańskimi, a zwłaszcza apokryficznymi biografiami Judasza. Bardzo podobny do tego typu jest wątek Grzegorz papiė̇ zawierający obok motywów charakterystycznych dla Edypa, także skontaminowane fragmenty legend osnutych wokół postaci historycznej, bp. Andrzeja z Krety, żyjącego na przełomie VII i VIII wieku. W obu zespołach przekazów spotykamy porzucone przez rodziców dziecko, które po osiągnięciu stosownego wieku rusza $\mathrm{W}$ świat. W konsekwencji różnych perypetii syn, nie rozpoznając swoich rodziców, zabija niechcący i nieświadomy ojca i żeni się ze swoją matką. Po ujawnieniu prawdy udaje się w kolejną wędrówkę pokutować za swoje straszne grzechy, co czyni na tyle solennie, cierpliwie i pokornie, że zyskuje przebaczenie od Boga (w Edypie) lub nawet tron apostolski (w Grzegorzu papieżu). Innymi słowy: kazirodztwo (i ojcobójstwo), jakkolwiek waloryzowane skrajnie negatywnie, dzięki odpowiedniej postawie protagonisty zostają wybaczone. Bajki składające się na te wątki przesiąknięte są na wskroś wymową moralną, nakazują pełne poddanie się woli Boga, który w swym miłosierdziu może podnieść z prochu nawet największego grzesznika.

Z sytuacją, którą nazwałby incestem $\mathrm{z}$ sobowtórem, spotykamy się w dwóch popularnych typach ludowych bajek magicznych. Pierwszy to T 317 Brat $i$ siostra. Traktuje o królestwie, którym rządził brat bez pamięci zakochany w swojej siostrze. Dziewczyna kilkakrotnie namawia go, by wyruszył w świat w poszukiwaniu małżonki, wyprawy jednak spełzają na niczym. Młodzieniec postanawia więc za wszelką cenę poślubić swoją siostrę. W dzień ślubu królewnie udaje się uciec albo do nieprzebytej puszczy, albo - częściej - zapada się pod ziemię, gdzie trafia do olbrzymiej jaskini. Tam też znajduje małą chałupkę, w której spotyka swojego sobowtóra, równą jej

${ }^{4}$ Oba typy fabularne zostały omówione przez Olgę Wachcińską (2011). Por. Grabowski 1892; Bystroń 1888. Zob. także pracę Włodzimierza Proppa (2000: 224), gdzie wspominano o pokrewnym, wschodniosłowiańskim typie Halban. 
w urodzie cud dziewicę, pilnowaną jednak przez okropną czarownicę - Zjadarkę (lub Matkę Boską!). Nakłoniwszy swoją siostrę-nie-siostrę, dziewczyny uciekaja $\mathrm{z}$ więzienia, rzucając za siebie przedmioty magiczne zamieniające się szereg przeszkód geograficznych (np. ze szczotki powstaje las, z ręcznika - morze, z kłębka wełny góry), które uniemożliwiają Zjadarce ich schwytanie, a czasami powodują jej śmierć. Znalazłszy się z powrotem w rodzinnym zamku, królewna przedstawia swojemu bratu uratowaną dziewczynę, ten zakochuje się w niej szczerze i natychmiast, co pieczętuje wielkim weselem.

Drugim typem, nieco podobnym do przywołanego, a zarazem ściśle związanym ze słynnym Kopciuszkiem (T 510A), jest Mysi kożuszek (T 510B). W królestwie przedstawianym w tych bajkach rządzi owdowiały król. Ma on jednak córkę równie urodziwą, co matka, i w każdym calu do niej podobną. Zakochawszy się w niej, postanawia związać się z córką małżeństwem. Ta jednak - co prawda, nieszczególnie zgorszona propozycją - stanowczo tym zakusom się sprzeciwia. Aby opóźnić date ślubu, stawia przed ojcem trzy lub cztery zadania, których celem jest zdobycie sukien: słonecznej, księżycowej, gwiaździstej (tej w pewnych wariantach nie ma) i wreszcie uszytej z wszy lub mysich skórek. Zwróćmy uwagę na nietypowość tego motywu w bajkach magicznych próbom niemal zawsze poddawani są młodzieńcy, synowie, junacy i siłacze, kawalerowie, a nie mężczyźni dojrzali, ojcowie, co wiąże się $\mathrm{z}$ niejednokrotnie podnoszonym $\mathrm{w}$ pracach folklorystów inicjacyjnym charakterem fabuł bajek magicznych (Sitniewska 2013). Królowi mimo trudności udaje się zdobyć upragnione przyodziewki, w wyniki czego księżniczka w dniu ślubu przebiera się w suknię najbardziej poślednią i ucieka z zamku. W lesie odnajduje wielki dąb, w którym ukrywa swe najstrojniejsze suknie, a sama rusza do grodu - albo tego, z którego uciekła, albo znajdującego się w innym królestwie. Tam najmuje się jako pomoc kucharza, ciężko pracuje, a promykiem rozświetlającym jej codzienny znój są bale (lub msze), w jakich z ochotą uczestniczy. Za każdym razem biorąc udział w zabawie (lub ceremonii) biegnie do dębu, z którego po wypowiedzeniu zaklęcia wydobywa coraz to piękniejszą suknię. Król zamku oczywiście porusza niebo i ziemię, by odnaleźć nadzwyczajną dziewczynę, znikającą mu z oczu na zakończenie każdej uroczystości. Dziewczynę przed władcą zdradza w końcu kucharz, a bajka znajduje swój szczęśliwy finał w hucznym weselu. Co charakterystyczne, w wariantach, w których dziewczyna po pierwszej ucieczce wróciła do swojego zamku, postać królaojca znika w rozwiązaniu bajki, pozostawiając odbiorcę w konfuzji, ilu właściwie władców rządziło tym grodem, natomiast w wariantach, w których księżniczka znalazła schronienie w innym królestwie, król-ojciec raduje się szczęściem córki, odwiedza ją i prowadzi bogatą korespondencję.

Literalnie rzecz biorąc, w obu typach bajek magicznych nie ma mowy o kazirodztwie. Nie sposób jednak nie zauważyć, że de facto tak jest. Podwojenie postaci królewny w wątku o Bracie $i$ siostrze i króla w Mysim kożuszku jest zabiegiem czysto formalnym, służącym, jak przypuszczam, zadośćuczynieniu dwóm przeciwstawnym tendencjom. To, że w ogóle są one obecne, jest znakiem czasu, tzn. bajki te w wersjach nam znanych być może powstawały w takim momencie, w którym nie można już było na poważnie odnieść się do trudnego do określenia archaicum, w jakim elementem jeśli nie centralnym, to jednym $\mathrm{z}$ podstawowych był mityczny związek kazirodczy pomiędzy bratem a siostrą (bliźniętami?), ponieważ zatracono o nim pamięć, ale też najzwyczajniej coraz bardziej odstawał on od epoki w zupełnie inny sposób opisującej i rozumiejącej rzeczywistość. Z drugiej strony, omawiane fabuły powstawały - znowu: być może - w na tyle nieodległym czasie od swych pierwotnych 
źródeł mitologicznych, że nadal uchwycić w nich można elementy dawnych wyobrażeń. Wydaje się, że obecność motywu „kazirodztwa-nie-kazirodztwa”, jest świadectwem rozdarcia między „starą" warstwą wyobrażeń i wątków mitologicznych a treściami płynącymi z nowej, chrześcijańskiej formacji światopoglądowej.

Tych kilka omówionych dotąd wątków to oczywiście materiał bardzo szczupły. Pozwala jednak wstępnie przyjąć, że jeśli w ogóle w tradycyjnym folklorze polskim (słowiańskim?) istotnie możemy mówić o jakimś mitycznym wzorcu incestu, to jest to zbliżenie rodzeństwa, za czym przemawia rozleglejszy materiał i obecność w działaniach rytualnych, opisanych przez Bajburina - zarazem kazirodztwo przedstawiane w Edypie i Grzegorzu papieżu odrzucam z racji ich bezdyskusyjnie nieludowego pochodzenia. Dalece jednak ważniejsze dla tej propozycji odczytania omawianego materiału, jest ścisłe powinowactwo zaprezentowanych bajek z wątków Brat $i$ siostra oraz Mysi kożuszek z olbrzymim zespołem przekazów magicznych opowiadających - najogólniej rzecz biorąc - o młodzieńcu ratującym cud dziewicę, więzioną przez smoka w jaskini, znajdującej się we wnętrzu góry. $\mathrm{Na}$ owe powinowactwo wskazują zarówno zespoły postaci, jak i przestrzenie pojawiające się w zaprezentowanych bajkach, a także rekwizyty i sytuacje: obraz jaskini, w jaką zapada się córka/siostra chcąca uniknąć ślubu z krewnym jest dokładnie taki sam, jak groty, w której uwięził ją smok; dąb, z którego wydobywa schowane suknie, jest zaprezentowany dokładnie tak samo jak dąb, rosnący na szczycie smoczej góry, bardzo przypominający - dodajmy - drzewo uobecnione w setkach podań lokalnych traktujących o wydobywaniu zeń płonących skarbów (lub złotych jaj); suknie ze szlachetnego kruszcu to przetransformowane złote, srebrne i miedziane jaja, z jakich powstają trzy królestwa w polskich T 301 Zdradzieccy towarzysze i w T 302 Dusza potwora $w$ jaju. „Uwięziona w jaskini” nie jest zresztą do końca trafnym określeniem dla sytuacji, w której ktoś spędza dnie całe na słodkim nieróbstwie, nie napastowany przez nikogo (potwór wszak nie wyrządza dziewczynie żadnej krzywdy, pozostając często poza jaskinią), otoczona wszelkimi dostatkami i zbytkami, a przede wszystkim troską swojego opiekuna - smoka, w którego okrucieństwo każą nam uwierzyć ludowi gawędziarze. Jak starałem się wykazać w innym miejscu, możliwym wytłumaczeniem tej cokolwiek zastanawiającej sytuacji jest założenie, że smok to po prostu ojciec królewny, a tym samym - i królewicza (Mianecki 2010; 2012).

Bajkę magiczną nie sposób odróżnić od mitu na poziomie analizy tekstowej - sa strukturalnie zbyt do siebie podobne. Odróżnia je funkcja, jaką pełnią w kulturze, ale ta widoczna jest dopiero wtedy, gdy podniesiemy wzrok znad tekstu i przyjrzymy się np. rzeczywistości rytuału - tak jak to zrobił np. Bajburin. Traktując bajkę magiczną jak potencjalną akcję obrzędu, a obrzęd - jak fabułę określonej (choć ukrytej) narracji, przyjrzyjmy się z tej podwójnej perspektywy elementom tradycyjnego wesela.

Blisko sto lat temu powstała chyba najobszerniejsza i zarazem koncepcyjnie najbardziej spójna monografia polskiego wesela ludowego, napisana przez, jak byśmy dziś powiedzieli, antropologa prawa, Władysława Abrahama (1925). Na szerokim tle ogólnosłowiańskim omawia on m.in. dwa momenty tego kompleksu obrzędowego, tzn. postrzyżyny weselne (swadziebne), których główną bohaterką była panna młoda, oraz pokładziny. Postrzyżyny były historycznie dawniejszą formą rytuału, którą później zastapiły tylko rozpleciny, stanowiące - w ramach samego rytuału - jedynie wstęp do postrzyżyn. Postrzyżyny polegały na całkowitym obcięciu panieńskiego warkocza lub tylko na podcięciu, ewentualnie opaleniu włosów. Czynność tę wykonywał najstarszy brat. Po jej dokonaniu obowiązkowo następował targ o warkocz, który w odpowiednim momencie także przerywał brat (pan młody zachowywał się całkowicie biernie). 
Zakupiony warkocz był rozplatany przez - znowu - brata; obyczaju tego bardzo pilnowano tak w Polsce, jak i dzisiejszej Litwie, Białorusi i Ukrainie. Niekiedy mógł to zrobić starszy drużba, ale, jak zobaczymy, na poziomie mitologiczno-symbolicznym nie jest to żaden dysonans. Rola drużby wzrasta po oczepinach, w których także uczestniczył jeszcze brat, często jako jedyny mężczyzna. Drużba zatem przygotowuje łoże na pokładziny, bywa że je wygrzewa, bije też cepem młodych po tym, jak się już w łóżku położą (pokładziny na większości terenów Słowiańszczyzny miały charakter publiczny). Drużba też czeka pod drzwiami, by w razie „niemocy” młodego dokonać w jego zastępstwie defloracji. Na południu istniała nawet zasada, że pierwszą noc młoda spędzała $\mathrm{z}$ drużbą, $\mathrm{w}$ regionach nam bliższych zastąpiono to szczególną zażyłością drużby i młodej wyrażaną w pieśniach. $Z$ drugiej strony, istniały też tereny (lub sytuacje), kiedy starszym drużbą był brat panny, co oczywiście wykluczało go z zajęć alkowianych. Zarówno przy postrzyżynach, jak i oczepinach sadzano dziewczynę na odwróconej dzieży chleba przykrytej białym obrusem lub kożuchem, przywodzącej na myśl ową kosmiczną górę - siedzibę smoka. Na koniec swojego opisu - który tu przywołuję w znacznym uproszczeniu - Abraham stawia pytanie: „(...) dlaczego on właśnie [brat] a nie ojciec kobiety przedsiębierze czynność postrzyżyn, widocznie jednak wypadało to $\mathrm{z}$ przyjętego rytuału. (...) może wreszcie istniał w ceremoniale weselnym jakiś podział ról na zasadach, których zgłębianie dziś nam z trudnością przychodzi, w każdym razie jednak stwierdzić musimy, że właśnie udział brata w postrzyżynach tem bardziej umacnia znaczenie prawne postrzyżyn (...)" (Abraham 1925: 233). W świetle tego wszystkiego, co do tej pory powiedzieliśmy, być może odpowiedź brzmi: w świecie uobecnionego mitu, jakim jest obrzęd, rzeczywisty brat krwi, który w porządku mitologicznym był mężem swojej siostry, poprzez towarzyszenie dziewczynie w każdym z kulminacyjnych momentów rytuału, niemal do samej alkowy, symbolicznie przekształca pana młodego $\mathrm{w}$ jej brata. W tym sensie w wariantach obrzędu, w jakich pojawia się starszy drużba jako swoisty pośrednik między jedną a drugą postacią męską, to $\mathrm{w}$ istocie też jest postać mitologicznego krewnego, tyle że multiplikowaną i ,asekuracyjnie” utworzoną w celu zapewnienia większego „bezpieczeństwa” magiczno-symbolicznego głównych protagonistów ceremonii przejścia. Innymi słowy, bez względu na to, kto po stronie męskiej bierze udział w pokładzinach - drużba czy nowy mąż - w płaszczyźnie mitu to ciągle byłby brat.

$\mathrm{Na}$ koniec zwróćmy jeszcze uwagę na to, co odnotował także Abraham, mianowicie: jak bardzo wyraźnie brakuje we wszystkich tych działaniach postaci ojca jest to brak podobnie intrygujący, jak w sytuacjach balladowych. Jeżeli jednak ojciec jest w perspektywie mitu smokiem, to został już pokonany - wszak był to warunek połączenia się siostry i brata. Pytanie zatem, z którym pozostajemy, brzmi: kiedy w sytuacji obrzędowej - to się stało? Odpowiedź mogą przynieść jedynie dalsze badania folkloru tradycyjnego uwzględniające opisy obrzędów ludowych utrwalone w XIX i na początku XX wieku. 


\section{Bibliografia}

ABRAHAM, W. (1925). Zawarcie matżeństwa $w$ pierwotnem prawie polskiem. Lwów: Towarzystwo Naukowe.

BAJBURIN, A.K. (1990). W sprawie opisu struktury słowiańskiego rytuatu budowniczego (przeł. B. Żyłko). „Polska Sztuka Ludowa”, 3, 62-69.

BARANOWSKI, B. (1955). Sprawy obyczajowe $w$ sadownictwie wiejskim $w$ Polsce w wieku XVII i XVIII. Łódź: Wydawnictwo Łódzkie.

BYstroń, J.S. (1888). Polskie podania ludowe spokrewnione ze średniowieczna legendą o św. Grzegorzu. „Wisła”, t. 2, 762-766.

GRABOWSKI, B. (1892). Podania o związach między najbliższym rodzeństwem. „Wisła”, t. 6, 54-79, 279-299.

Graves, R. (1974). Mity greckie (przeł. H. Krzeczkowski). Warszawa: Państwowy Instytut Wydawniczy.

Gromska, J., MASŁowski, J., SMOKTUNowiCZ, I. (2002). Badanie przyczyn kazirodztwa na podstawie analizy opinii sadowych. „Psychiatria w Praktyce Ogólnolekarskiej”, 4 (2), 267-272.

Gustawicz, B. (1882). Podania, przesady, gadki $i$ nazwy ludowe $w$ dziedzinie przyrody. „Zbiór Wiadomości do Antropologii Krajowej”, 6, 201-317.

HeRnas, Cz. (1965). U źródet folklorystyki polskiej. Warszawa: Państwowy Instytut Wydawniczy.

KAMLER, M. (2010). Złoczyńcy: przestepczość $w$ Koronie $w$ drugiej połowie XVI $i$ w pierwszej połowie XVII wieku (w świetle ksiag sądowych miejskich). Warszawa: Wydawnictwo Neriton.

Krawiec, A. (2000). Seksualność w średniowiecznej Polsce. Poznań: Wydawnictwo Poznańskie.

KRZYŻANOWSKI, J. (1962-1963). Polska bajka ludowa w uktadzie systematycznym. T. 1-2. Wrocław: Zakład Narodowy im. Ossolińskich - Wydawnictwo Polskiej Akademii Nauk.

KUCHOwICZ, Z. (1982). Miłość staropolska: wzory - uczuciowość - obyczaje erotyczne XVI-XVIII wieku. Łódź: Wydawnictwo Łódzkie.

LÉVI-STRAUSS, C. (2011). Elementarne struktury pokrewieństwa (przeł. M. Falski). Warszawa: Oficyna Wydawnicza Volumen.

MALINOWSKI, B. (1980). Zwyczaj i zbrodnia w społeczności dzikich; Życie seksualne dzikich $w$ pótnocno-zachodniej Melanezji: miłość, matżeństwo $i$ życie rodzinne u krajowców z Wysp Trobrianda Brytyjskiej Nowej Gwinei (przeł. J. Obrębski, J. Chałasiński, A. Waligórski). Warszawa: Państwowe Wydawnictwo Naukowe.

MALINOWSKI, B. (1987). Seks i sttumienie $w$ społeczności dzikich oraz inne studia o płci, rodzinie i stosunkach pokrewieństwa (przeł. B. Golda, G. Kubica, Z. Mach). Warszawa: Państwowe Wydawnictwo Naukowe.

MAtUSiaK, Sz. (1881). Nasze kwiaty polne. Kraków: Wydawnictwa „Przeglądu Akademickiego".

MiANECKI, A. (2010). O skarbach w wybranych podaniach ludowych. W: P. Kowalski (red.), Monety, banknoty $i$ inne środki wymiany. Pieniadz $w$ dyskursach kultury (s. 6171). Wrocław: Wydawnictwo Uniwersytetu Wrocławskiego. 
MiANECKI, A. (2012). Przekleństwo królów, plaga królestw - smok w wybranych wątkach polskiego folkloru tradycyjnego. W: K. Konarska, P. Kowalski (red.), Powodzie, plagi, zycie $i$ inne katastrofy (s. 477-494). Wrocław: Wydawnictwo Uniwersytetu Wrocławskiego.

MoDZELEWSKI, K. (2004). Barbarzyńska Europa, Warszawa: „Iskry”.

PROPP, W. (2000). Nie tylko bajka (wybór i tł. D. Ulicka). Warszawa: Wydawnictwo Naukowe PWN

Przestępstwa przeciwko wolności seksualnej i obyczajowości (197-205). Pozyskano z: http://www.statystyka.policja.pl/portal/st/1108/63502/Kazirodztwo_art_201.html.

RACZEK, E. (2012). Kazirodztwo - ujęcie sądowo-genetyczne. „Archiwum Medycyny Sądowej i Kryminologii”, 1 (62), 55-63.

SITNIEWSKA, R. (2013). Rola ojca $w$ procesie inicjacji dziecka na przykładzie wybranych watków ludowej bajki magicznej. „Literatura Ludowa”, 4/5, 61-73.

Stone, L. (2012). Pokrewieństwo i pleć kulturowa (przeł. W. Usakiewicz). Kraków: Wydawnictwo Uniwersytetu Jagiellońskiego.

SZYMCZAK, M. (1966). Nazwy stopni pokrewieństwa $i$ powinowactwa rodzinnego $w$ historii $i$ dialektach języka polskiego (przedm. W. Doroszewski). Warszawa: Państwowe Wydawnictwo Naukowe.

SZYMCZAK, M. (1988). Słownik języka polskiego. T. 1. Warszawa: Państwowe Wydawnictwo Naukowe.

Ustawa z dnia 6 czerwca 1997 r. Kodeks karny, art. 201 (Dz.U. z 1997 Nr 88, poz. 553).

WACHCIŃSKA, O. (2011). Folklorystyczne i literackie wędrówki wątku o królu Edypie. „Tekstura”, 2, 159-176.

WĘŻOWICZ-ZIÓŁKOWSKA, D. (1991). Miłość ludowa: wzory miłości wieśniaczej w polskiej pieśni ludowej XVIII-XX wieku. Wrocław: Polskie Towarzystwo Ludoznawcze.

WIŚLICZ, T. (2001). Zarobić na duszne zbawienie: religijność chłopów małopolskich od połowy XVI do końca XVIII wieku. Warszawa: Wydawnictwo Neriton.

WIŚLICZ, T. (2004). Z zagadnień obyczajowości seksualnej chłopów w Polsce XVIXVIII wieku: przyzwolenie i penalizacja. „Lud”, 88, 41-63.

WRÓBLEWSKA, V. (2007). Ludowa bajka nowelistyczna: źródła - wątki - konwencje. Toruń: Wydawnictwo Naukowe Uniwersytetu Mikołaja Kopernika. 


\section{ADRIAN MiANECKI}

THE INCEST Motif IN POLISH TRADITIONAL FOLKLORE

The article proposes an analysis of traditional folklore texts with regard to the motif of incest between sister and brother. The author points out that although the title motif is occasionally referred to explicitly, its veiled forms seem to occur almost universally, especially in folklore prose. At the same time references to incest symbolism can also be found in specific ritual situations. The author argues that the popularity of this motif is a reverberation of old mythological images stemming from a marriage between siblings. 